\title{
Croatian court vindicates journal editor
}

A Croatian disputes settlement court has annulled a public reprimand against the coeditor of the Croatian Medical Journal and reaffirmed his right to speak publicly about the "moral and intellectual crisis of the Croatian academic community."

Dr. Matko Marusic, who remains coeditor of the journal along with his wife Ana Marusic, went public with his opinions in an October 2007 article published in the weekly Catholic newspaper The Voice of Council after his former employer, the University of Zagreb School of Medicine, refused to deal adequately with seven allegations of plagiarism and duplicate publication against retired professor of obstetrics and gynecology Dr. Assim Kurjak. The journal subsequently retracted two articles that it, as well as another journal, had published.

In November 2007, the university's Court of Honour acknowledged that Kurjak had behaved unethically, but judged that as he had retired, an apology was adequate and dismissed the case. Believing that decision implicitly sanctioned Kurjak's behaviour, Marusic - now dean of the Split School of Medicine - went to the lay media. In May 2008, he was reprimanded by the university's council for doing so (CMAJ 2008;178[13]:1637-8).

"Most of the time, editors do not need to take public actions in the scientific community, but there are times when they have to speak in defense of integrity of science," Marusic states in an email to CMAJ.

On Nov. 21, 2008, the Administrative Court of Croatia, a judicial dispute settlement body, upheld Marusic's complaint against the University of Zagreb School of Medicine's Council and annulled its misconduct penalty. It further ruled Marusic's constitutional rights had been violated when the school's Committee for Disciplinary Proceedings asked for three psychiatric assessments. Essentially, the court condemned the use of psychiatry to defame an academic colleague.

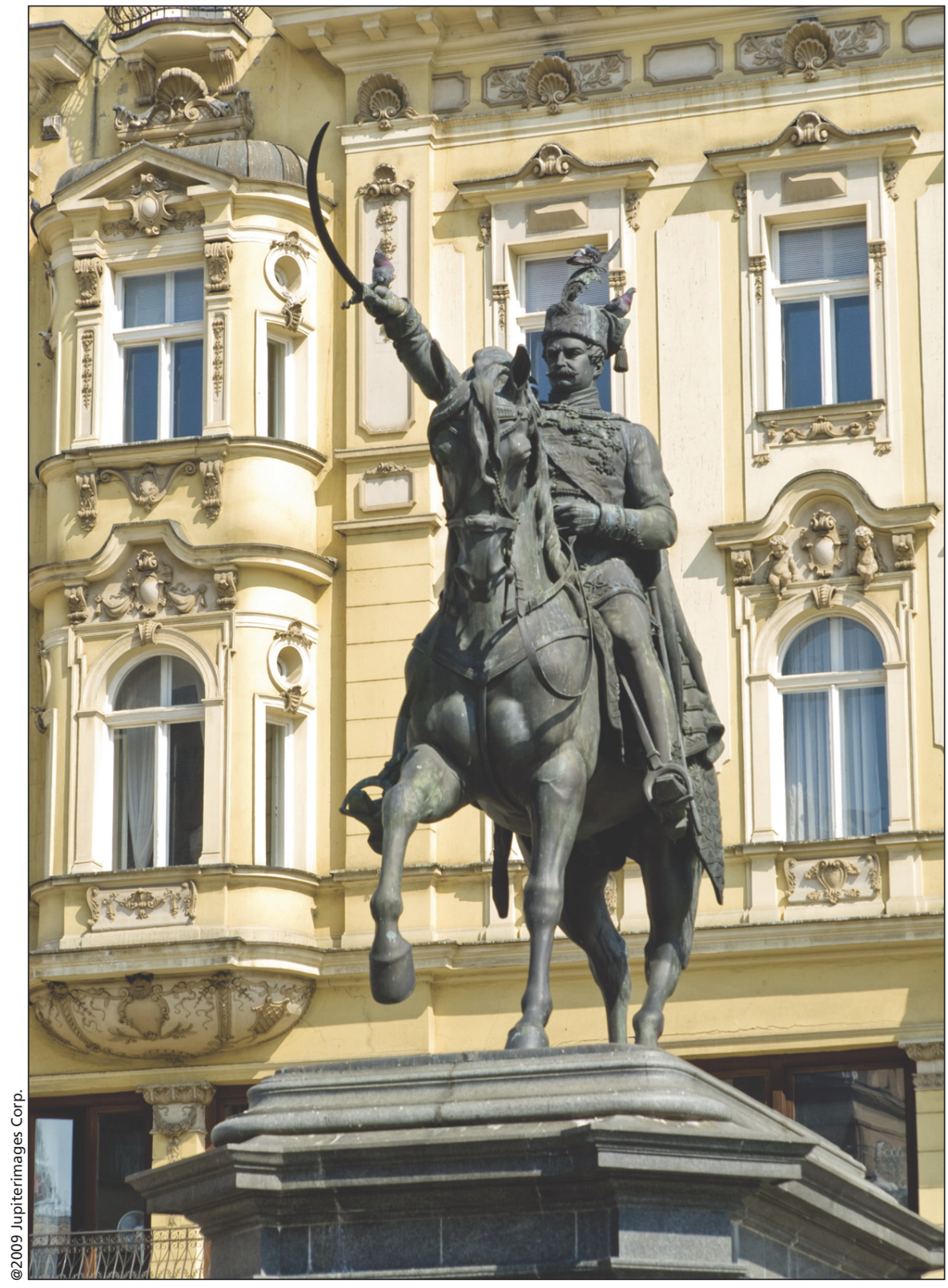

A court casts a controversy which has rocked Zagreb as the "moral and intellectual crisis of the Croatian academic community."

University of Zagreb officials have neither apologized nor compensated Marusic in response to the court's ruling. Nor have they issued any sanctions.

In fact, Rector Dr. Aleksa Bjelis states in an email that legal experts have informed him that "the authority of the Administrative Court in [this] matter is questionable." The university is pursuing the matter

Dean of Medicine Dr. Nada Cikes states in an email that, as the owners of the Croatian Medical Journal, the university "has the responsibility to look into possible irregularities such as the unacceptable acts of the editors." 
While Marusic finds the university's response disappointing, he states in an email that he "feels vindicated, personally, and as a citizen of Croatia," by the Administrative Court's decision. It's a "hallmark in judicial support for the freedom of speech, defining academic autonomy and respect for law and administrative procedures and the right to a fair trial."

The Administrative Court was not alone in its admonition about the use of psychiatrists.
In a May 13 statement, the Croatian Helsinki Committee for Human Rights stated that the case involved "misuse of psychiatry" that violated "not only the human rights of Prof. Marusic, but also his dignity." As well, it found that resolution of the dispute had not been timely.

But Bjelis says the human rights committee formulated its position "without gaining insight into the procedures taken at the school."

In the midst of the dispute, in March
2008, the Zagreb School of Medicine, one of four owners of the journal, sought to change its governance structure, striking the word "independent" from its governance document and allowing medical deans to appoint or dismiss members of its editorial board. The restructuring did not occur but should it proceed, Marusic believes it would effectively make the journal a house organ of the university. - Barbara Sibbald, CMAJ

DOI:10.1503/cmaj.109-3030 